American University Washington College of Law

Digital Commons @ American University Washington College of

Law

Articles in Law Reviews \& Other Academic Journals

Scholarship \& Research

2015

Earned Sovereignty Revisited: Creating a Strategic Framework for Managing Self-Determination Based Conflicts

Paul Williams

Carlie Armstrong

Abigail Avoryie

Follow this and additional works at: https://digitalcommons.wcl.american.edu/facsch_lawrev

Part of the International Law Commons 


\title{
EARNED SOVEREIGNTY REVISITED: CREATING A STRATEGIC FRAMEWORK FOR MANAGING SELF-DETERMINATION BASED CONFLICTS
}

\author{
Paul R. Williams, ${ }^{*}$ Abigail J. Avoryie, ${ }^{* *} \&$ Carlie J. Armstrong ${ }^{* *}$
}

I. INTRODUCTION.

II. DANGEROUS LEGACY OF SOVEREIGNTY-BASED CONFLICTS:

DEADLY, DURABLE, AND DESTABILIZING

III. FALSE SECURITY IN ECONOMIC PROSPERITY AND REGIONAL INTEGRATION: EUROPE'S FAILED SELF-DETERMINATION

POLICY

IV. SOVEREIGNTY-FIRST AND THE FAILURE TO ESTABLISH VIABLE

NEW STATES

V. LOOKING FORWARD: UTILIZING EARNED SOVEREIGNTY AS A STRATEGIC FRAMEWORK FOR MANAGING SELFDETERMINATION BASED CONFLICTS

VI. CONCLUSION .448

\section{INTRODUCTION ${ }^{1}$}

Self-determination movements ${ }^{2}$ are global phenomena that perpetually tug at the strings of a world order based on the principles of sovereignty and

* Dr. Paul R. Williams is the Rebecca I. Grazier Professor of Law and International Relations at American University. He is also the co-founder and President of the Public International Law.\& Policy Group (PILPG), a global pro bono law firm providing assistance to parties engaged in peace negotiations and drafting post-conflict constitutions. PhD Cambridge, JD Stanford Law School, AB UC Davis. Dr. Williams has advised nearly two dozen states and governments on peace negotiations and drafting post-conflict constitutions. The authors are grateful to Melissa Benedict for her outstanding research contributions.

** Abigail Avoryie is a Law Fellow at PILPG providing legal assistance on PILPG's Syria and Yemen projects. Prior to joining PILPG, she worked in Chambers at the United Nations International Criminal Tribunal for Rwanda.

*** Carlie Armstrong is a Senior Research Associate supporting PILPG's work in Syria and Yemen on issues of peace negotiation and constitutional reform.

1. This article is adapted from a speech given by Dr. Paul Williams in 2014 at the annual International Law Weekend Conference in New York.

2. The term self-determination in this article is used to characterize the various movements around the world where populations are seeking to gain greater political autonomy. Complete independence is not necessarily the ultimate, or necessary outcome of self-determination movements. Rather, this article views self-determination movements as dynamic and nuanced with the ultimate outcomes and goals greatly varying by state. In some instances a system of shared sovereignty may benefit parties, in other instances the solution may be to remain unified. Ultimately there are several potential outcomes to self-determination movements. 
territorial integrity. ${ }^{3}$ Despite the near constant and widespread reaffirmation of state sovereignty and territorial integrity by the international community, in the last twenty-five years nearly three-dozen new states have emerged.

Some new states have arisen from the dissolution of states, while others have seceded from states which then continue to exist, and a few have emerged from the last vestiges of colonialism/trusteeship. A number of other sub-state entities have gained substantially enhanced autonomy as a result of efforts to exercise greater self-determination. Sub-state entities are achieving statehood or enhanced autonomy in a wide range of geographic locations-including Africa, Asia, Eurasia, Europe, and the Western Hemisphere-and from a broad spectrum of geopolitical contexts, including democratic, authoritarian, totalitarian and post-conflict transitional systems. ${ }^{4}$

Currently, there are over seventy active self-determination movements around the globe, and this trend seems far from dissipating. ${ }^{5}$ Many of these self-determination movements generate sovereignty-based conflicts

3. See generally Ved P. Nanda, Self-Determination Outside the Colonial Context: The Birth of Bangladesh in Retrospect, 1 Hous. J. INT'L L. 71, 93 (1978-1979); Ved P. Nanda, Self-Determination in International Law-The Tragic Tale of Two Cities - Islamabad (West Pakistan) and Dacca (East Pakistan), 66 AM. J. INT'L L. 321, 322 (1972); Ved P. Nanda, The New Dynamics of Self-Determination: Revisiting Self-Determination as an International Law Concept: A Major Challenge in the Post-Cold War Era, 3 ILSA J. INT'L \& COMP. L. 443, 444 (1997).

4. See Matt Rosenberg, NEW COUNTRIES OF THE WORLD: The 34 New Countries Created Since 1990 (2015), http:/geography.about.com/cs/countries/a/newcountries.htm (last visited Feb. 7, 2015); see Adam Taylor, The 9 Newest Countries in the World, WASH. POST (Sept. 16, 2014), available at http://www.washingtonpost.com/blogs/worldviews/wp/2014/09/16/the-9-newest-countries-in-theworld/ (last visited Feb. 7, 2015). Recently independent states include: Armenia, Sept. 21, 1991; Azerbaijan, Aug. 30, 1991; Belarus, Aug. 25, 1991; Estonia, Sept. 6, 1991; Georgia, Apr. 9, 1991; Kazakhstan, Dec. 16, 1991; Kyrgyzstan, Aug. 21, 1991; Latvia, Sept. 6, 1991; Lithuania, Mar. 11; 1990 (officially recognized Sept. 17, 1991); Moldova, Aug. 27, 1991; Russia, Aug. 24, 1991; Tajikistan, Sept. 9, 1991; Turkmenistan, Oct. 27, 1991; Ukraine, Nov. 24, 1991; Uzbekistan, Sept. 1, 1991; Croatia, June 25, 1991; Slovenia, June 25, 1991; Macedonia: Sept. 8, 1991 \& Sept. 17, 1991; Bosnia and Herzegovina, Feb. 29, 1992; Serbia and Montenegro (as the Federal Republic of Yugoslavia), Apr. 17, 1992; The Czech Republic, Jan. 1, 1993; Slovakia, Jan. 1, 1993; Eritrea, May 25, 1993; East Timor (Timor-Leste), May 20, 2002; Montenegro, June 3, 2006; Serbia, June 5, 2006; Kosovo, Feb. 17, 2008; South Sudan, July 9, 2011.

5. See Separatist Movements: Should Nations Have a Right to Self-Determination?, 2 CQ GLOBAL RESEARCHERS, 85, 89 (2008), available at http://www.cqpress.com/docs/AffiliationsPDFs/ separatists.pdf (last visited February 7, 2015); see generally W Alejandro Sanchez \& Kimberly Bullard, On Separatism in Latin America, E-INT'L RELATIONS, (May 20, 2013), http://www.eir.info/2013/05/20/on-separatism-in-latin-america/ (last visited Feb. 7, 2015); Rick Noack, These 8 places in Europe could be the next to try for independence, WASH. POST (Sept. 18, 2014), available at http:/www.washingtonpost.com/blogs/worldviews/wp/2014/09/18/if-scotland-breaks-away-these-8places-in-europe-could-be-next/ (last visited Feb. 7, 2015). 
characterized by extreme violence on the part of both the parent state and the sub-state entity, and by the potential for regional and international instability. ${ }^{6}$ Many of the current self-determination movements span several generations, and are characterized by periods of revival and decline.

While three-dozen new states have emerged in the past twenty-five years, the international community has yet to settle on an effective framework for managing self-determination movements and their often accompanying sovereignty-based conflicts. The failure to create an effective strategic framework has harrowing consequences. Over twenty million people around the world have died in sovereignty-based conflicts. ${ }^{7}$

Traditionally, sovereignty-based conflicts are addressed in one of two ways, the "sovereignty first" approach, or the "self-determination first" approach. "The predominant approach of 'sovereignty first' is typically used by states wishing to preserve sovereignty and territorial integrity." In this approach, sovereignty is regarded as the foundation of statehood and a cornerstone of international law. ${ }^{10}$ Alternatively, the "self-determination first" approach is most often used by secessionist movements, and presumes that all dependent peoples are entitled to exercise selfgovernment and live free of persecution. ${ }^{11}$

6. See Paul Williams \& Francesca Jannotti Pecci, Earned Sovereignty: Bridging the Gap Between Sovereignty and Self-Determination, 40 STAN. J. INT'L L. 349, 352 (2004) (In the article the authors identify sovereignty-based conflicts and examine their main characteristics as: (1) difficult to resolve, (2) frequently give rise to terrorism, (3) give rise to human rights violation, and (4) poorly managed by existing international law).

7. This number is derived from compiling estimated death tolls from sovereignty-based conflicts around the world. This number includes civilian casualties and includes conflicts dating from 1945 to 2014. See Milton LeItenberg, Deaths In Wars and Conflicts IN THE 20th CENTURY 4 (3d ed. 2006), available at http://www.clingendael.nl/sites/default/files/20060800_cdsp_ occ_leitenberg.pdf (last visited Feb. 7, 2015).

8. See generally HURST HANNUM, AUTONOMY, SOVEREIGNTY AND SELF DETERMINATION: THE ACCOMMOdation of CONFlicting Rights (rev, ed., 1996); HidEAKI SHINODA, REEXAMINING SOVEREIGNTY: From Classical THEORY to the Global AGE (2000); Antony Anghie, Colonialism and the Birth of International Institutions: Sovereignty, Economy, and the Mandate System of the League of Nations, 34 N.Y.U. J. INT'L L. \& POL. 513 (2002); Anne Bodley, Weakening the Principle of Sovereignty in International Law: The International Criminal Tribunal for the Former Yugoslavia, 31 N.Y.U. J. INT'L L. \& POL. 417 (1999); Ronald A. Brand, External Sovereignty and International, 18 FORDHAM INT'L L.J. 1685 (1995).

9. Williams \& Pecci, supra note 6 , at 352.

10. Jamie Scudder, Territorial Integrity 1: Modern States and the International System, EXPLORING GEOPOLITICS (2010), http://www.exploringgeopolitics.org/publication_scudder_jamie_ territorial_integrity_modern_states_international_political_system_jurisdiction_peace_westphalia_leban on_somalia/ (last visited Feb. 7 2015).

11. See Williams \& Pecci, supra note 6, at 352 . 
When used exclusively, neither approach has little utility beyond providing a legal or political shield that states and sub-state entities rely upon to justify their actions or inactions. Instead of providing a starting point to solve conflicts, these seemingly mutually-exclusive approaches often create an ideological impasse that is difficult to navigate towards a peaceful resolution. Both failing to provide a path for peaceful resolution, these traditional approaches are inadequate.

In order to successfully resolve the persistent and growing number of violent and non-violent sovereignty-based conflicts, the international community must develop a strategic framework to guide resolution of these conflicts. Few states currently engaged in sovereignty-based conflicts have established a transparent and equitable approach to dealing with the issue of self-determination. Similarly third-party states called upon to mediate or assist with the resolution of such conflicts also lack a consistent or effective approach.

It is important to note that this article does not attempt to prescribe independence as a solution to all sovereignty-based conflicts. Rather, this article advocates for the creation of a strategic framework that allows parties to reach their own resolutions to the self-determination question in a way that minimizes violence and instability. As previously noted, to date, no comprehensive strategic framework exists and the status quo promotes a nebulous approach to managing self-determination movements, ultimately fostering an atmosphere of apprehension, instability and uncertainty at the mere mention of potential independence. It is within this atmosphere that conflict and violence become imminent.

This article aims to encourage the international community to create a strategic framework for managing sovereignty-based conflicts. First, this article examines the deadly, durable and destabilizing nature of selfdetermination movements that give rise to the need for a strategic framework. Second, this article challenges the commonly held belief that increased economic prosperity and regional integration can quell current and future self-determination movements. Third, this article illustrates how the sovereignty-first approach results in missed opportunities for developing sustainable institutions in newly independent states. Finally, the article calls for a reevaluation and expansion of the conflict resolution approach of earned sovereignty as a means for resolving sovereignty-based conflicts and giving non-violent voice to self-determination movements. 


\section{DANGEROUS Legacy OF SOVEREIGNTY-BASED CONFLICTS: DEADLY, DURABLE, AND DESTABILIZING}

Since 1990, almost half of the world's conflicts have been related to self-determination movements that seek greater autonomy or statehood. ${ }^{12}$ Although sovereignty-based conflicts often appear as contained within a particular territory, such crises are intimately connected to regional and global dynamics, ${ }^{13}$ and often give rise to the commission of mass human rights violations, population displacement, and terrorism. ${ }^{14}$ At their core, these conflicts are deadly, durable and destabilizing.

The predominate approaches to dealing with self-determination movements and the accompanying sovereignty based conflicts creates a dynamic where parties are encouraged to fight their way to independence. ${ }^{15}$ Unaddressed self-determination movements yield a considerable death toll that the international community often fails to acknowledge. For instance, the twenty-year war of separation between North and South Sudan left more than 2,000,000 dead, and displaced millions of others from their homes. ${ }^{16}$ Similarly, the three-year Nigerian Biafran war for secession resulted in an estimated $1,000,000$ casualties, with some calculations doubling or even tripling that number. ${ }^{17}$ In Sri Lanka, the Tamil population's efforts to secure self-determination have led to over 65,000 deaths since 1984. ${ }^{18}$ The Chechen wars for independence resulted in over 160,000 casualties. $^{19}$ In a single day, Saddam Hussein's government killed 5,000 people in the Kurdish-controlled town of Halabja through the use of gas and nerve agents in an effort to suppress Kurdish moves for self-

12. See Monica Duffy Toft, Self-Determination, Secession, and Civil War, Terrorism and Political Violence, 24 KENNEDY SCHOOL OF GOV. 4, 581-82 (July 31, 2012).

13. See generally MYRON WEINER, THE MACEDONLAN SYNDROME, WORLd POLITICS 665 (1971); see also MYRON WIENER, Bad Neighbors, Bad Neighborhoods: An Inquiry into the Causes of Refugee Flows, 21:1 INTERNATIONAL SECURITY 5 (1996); see also SuSAN OlzaK, THE GlobaL DYNAMICS OF RACIAL AND ETHNIC MOBILIZATION (2006).

14. Williams \& Pecci, supra note 6, at 349.

15. Paul Williams, ASIL Speech: International Law, Politics, and the Future of Kosovo, (Feb. $17,2008)$.

16. Modern Conflicts: Conflict Profile: Sudan (North-South Ethnic War), POLITICAL ECONOMY RESEARCH INSTITUTE (1983-2005), available at http://www.peri.umass.edu/fileadmin/ pdf/Sudan1.pdf (last visited Feb. 7, 2015).

17. Nigeria Biafran War, NECROMETRICS (2011), http://necrometrics.com/20clm.htm\#Biafra (last visited Feb. 7 2015).

18. Williams \& Pecci, supra note 6, at 347.

19. Chechen official puts death toll for 2 wars at up to 160,000, N.Y. TIMES (Aug. 16, 2005), available at http://www.nytimes.com/2005/08/15/world/europe/15iht-chech.html?_r=0 (last visited Feb. 7, 2015). 
determination..$^{20}$ Additionally, in just four years, the wars of secession in the territory of the former Yugoslavia left between 150,000 and 200,000 people dead. $^{21}$

In addition to the devastating human toll these conflicts exact, these crises are dangerously durable. A study of sovereignty-based conflicts over nearly half a century found that only twenty-four of the seventy-two active conflicts had been resolved. ${ }^{22}$ The average length of such conflicts was nearly thirty years. ${ }^{23}$ Furthermore, in assessing duration of civil conflicts overall, sovereignty-based conflicts demonstrate greater longevity than other internal conflicts. ${ }^{24}$

For instance, the self-determination aspirations of the Oromo in Ethiopia have persisted since before the 1974 fall of the imperialist regime. ${ }^{25}$ The Oromo are Ethiopia's largest ethnic group; however, they were subjugated by Ethiopia's Amhara imperialist government and displaced and disenfranchised by the subsequent military regime. ${ }^{26}$ The Oromo Liberation Front (OLF) emerged amid calls for self-determination for the Oromo people. In 1991, a new government took control of Ethiopia, promising greater autonomy and devolution of power to the state's linguistically/ethnically-based administrative units, including the Oromia region. ${ }^{27}$ The Oromo, however, argue that persistent centralization of power by the ruling party and failure to include the Oromo in shared decision-making has prompted the protracted conflict between the OLF and Ethiopian government that has claimed over 750,000 lives. ${ }^{28}$

20. IRAQI KURDS MARK 25 YEARS SINCE HALABJA GAS ATTACK, BBC.COM (Mar. 3, 2013), http://www.bbc.com/news/world-middle-east-21814734 (last visited Feb. 7, 2015).

21. See Jutta Paczulla, The Long, Difficult Road to Dayton: Peace Efforts in BosniaHerzegovina, 60 INT'L J. 255, 256-57 (Winter 2004/2005); Eric C. Martin and Judith L. Miller, NGOs and the Development of Bosnia and Herzegovina: Understanding Large-Scale Interorganizational Systems, 14 INT'L J. OF VOLUNTARY AND NONPROFIT ORGS. 145, 146 (June 2003).

22. Monty G. Marhall \& Ted Robert GuRr, Peace and Conflict 2003: A Global SURVEY OF ARMED CONFLICTS, SELF DETERMINATION MOVEMENTS AND DEMOCRACY 26-30 (2003).

23. Id.

24. See generally Halvard Buhaug, Scott Gates \& Paivi Lujala, Geography, Rebel Capacity, and the Duration of Civil Conflict, 53 J. OF CIV. CoNFLICT 544, 564 (2009).

25. Merera Gudina, Ethnicity, Democratization and Decentralization in Ethiopia, 23 EASSRA $81,88-90$ (2007).

26. See generally Mohammed Hassen, Conquest, Tyranny, and Ethnocide Against the Oromo, 9 N.E. AFR. STUD. 15, 18 (2002); see also Gudina, supra note 25, at 87.

27. See Gudina, supra note 25 , at 91 .

28. See generally id at 92; GENOCIDE WATCH, Genocides, Politicides, and Other Mass Murders Since 1945, http://www.genocidewatch.org/genocide/genocidespoliticides.html (last visited Feb. 7 2015) 
Not only do these durable conflicts result in great devastation and death, they also risk a deepening of the conflict as time goes on. The sixtyyear conflict between the Naga and the Indian government demonstrates how these conflicts evolve and persist in the absence of a strategic framework for their resolution. The Naga people occupy the northeast region of India along the Burmese border. ${ }^{29}$ At the time of India's independence from the British Empire, the Naga also sought to assert their right to self-determination by declaring independence a day before India's declaration. ${ }^{30}$ India firmly rejected the Naga's claim for independence and early peace agreements faltered. ${ }^{31}$ Staunch in their calls for selfdetermination, the Naga held two referendums for independence. ${ }^{32}$ The first, held in 1947 , and the Indian government immediately rejected it. ${ }^{33}$ The second, held in 1951, claimed ninety-nine percent participation among the Naga and was submitted to the United Nations, the British government, and Indian government; ${ }^{34}$ all refused to recognize its legitimacy. ${ }^{35}$

In the years that followed, the Indian government assumed a containment approach toward the situation of the Naga that served only to worsen the violence. ${ }^{36}$ The Indian government banned some of the prominent Naga political organizations and intentionally kept them out of critical negotiations on the status of the Naga and the designation of the state of Nagaland. ${ }^{37}$ In developing a policy for the Naga region, the Indian government often chose to negotiate with representatives of less relevant groups, thereby widening fissures within the Naga political structure and rekindling the violence both against the government and between the parties. ${ }^{38}$ Additionally, some commentators argue the Indian government has prioritized negotiation with too few factions and has neglected other relevant political actors. ${ }^{39}$ Failure to consult the relevant actors and

29. M. Amarjeet Singh, Revisiting the Naga Conflict: What Can India Do to Resolve this Conflict?, 24 SMALL WARS \& INSURGENCIES 794, 795 (2013).

30. See id.

31. Id.

32. Id.

33. Id.

34. Singh, supra note 29 , at 800 .

35. Id.

36. See generally Phyoben Odyuo, India's Conflict Management Strategy in the Northeast: The Case of Indo-Naga Conflict, ACADEMIA.EDU (2015), available at http://www.academia.edu/ 4284477/Indias_strategy_1 (last visited Jan. 28, 2015).

37. See Singh, supra note 29 , at 800-02.

38. See id., at 802-03.

39. See id. at 804. 
seriously address the Naga calls for self-determination have resulted in persistent tension and violence between the state of Nagaland and its neighboring states with significant Naga populations. ${ }^{40}$ In failing to implement a strategic framework to address the Naga self-determination calls, the Indian government has prolonged an ongoing conflict with potentially regionally destabilizing effects. ${ }^{41}$

As sovereignty-based conflicts persist and worsen, they have a destabilizing effect not merely internally but also regionally and even globally. The havoc these conflicts inflict generates a number of destabilizing outcomes, such as large refugee populations, the establishment of war economies, and terrorist safe havens that cause additional fighting and deaths. As the secessionist wars in the former Yugoslavia demonstrate, sovereignty-based conflicts can devastate a region. The international community's failure to act swiftly to resolve the conflicts in Slovenia and Croatia allowed the fighting to spread to Bosnia. Between 150,000 and 200,000 people perished between 1991 and $1995 .{ }^{42}$ Only three years later, ongoing ethnically-based violence in Serbian-controlled Kosovo displaced nearly ninety-percent of the area's Albanian population. ${ }^{43}$ Despite the North Atlantic Treaty Organization (NATO)-led international intervention and corresponding financial backing, thousands perished and nearly $1,000,000$ were expelled. ${ }^{44}$

As Kosovo highlights, these conflicts frequently result in the creation of large refugee populations, which can destabilize and strain neighboring states as they attempt to absorb those fleeing the violence. Indeed, large influxes of refugees have been linked to destabilizing effects in the host state, such as environmental degradation and scarcity, radicalization, civil war spillover, and interstate tension and conflict. ${ }^{45}$ Furthermore, it has been

40. See M. Amarjeet Singh, NIAS Backgrounder on Conflict Resolution: The Naga Conflict, NIAS (2012), available at http:/www.nias.res.in/docs/B7-Naga.pdf (last visited Feb. 7 2015); Singh, supra note 29, at 805-06; Army Called in After Deadly India Violence, ALJAZEERA (Aug. 21, 2014), available at http:/www.aljazeera.com/news/asia/2014/08/army-called-after-deadly-india-violence2014821112929893844.html (last visited Jan. 28, 2015).

41. See Army Called in After Deadly India Violence, supra note 40.

42. Charles R. Figley, TRaumatology of GrieVing 24 (2013).

43. War in Europe-Facts \& Figures, PBS (2014), available at http://www.pbs.org/wgbh/pages/frontline/shows/kosovo/etc/facts.html (last visited Jan. 28, 2015).

44. Id:; Kosovo Conflict, ENCYClOPEDIA BRTTANNICA (2015), available at http://www.britannica.com/EBchecked/topic/1380469/Kosovo-conflict (last visited Apr. 2, 2015).

45. See Adrian Martin, Environmental Conflict Between Refugee and Host Communities, $42 \mathrm{~J}$. of PEACE REsearch 329, 332 (2005); Idean Salehyan \& Kristian Skrede Gleditsch, Refugees and the Spread of Civil War, 60 INTERNATIONAL ORGANIZATION 335, 338 (2006); Idean Salehyan, The 
posited that refugee flows, rather than being a mere externality of conflict, may actually catalyze conflict within and between states. ${ }^{46}$ Conflict between states may arise due to the presence of opposition leaders and fighters in refugee camps, which may prompt the home state to launch attacks against the camps within the territorial borders of the host state. ${ }^{47}$ Additionally, armed opposition groups within the refugee populations may seek out alliances with sympathetic local groups in the host state, thereby intensifying underlying internal strife and conflict. ${ }^{48}$

The destabilizing impact of refugees on the host state is exacerbated by resource scarcity. For instance, the estimated 165,000 Sahrawi refugees living in Algeria rely exclusively on humanitarian assistance and lack opportunities for self-sufficiency. ${ }^{49}$ The United Nations (UN) estimates that four-fifths of the world's eleven million refugees live in the developing world, where the host states are less able to support them. ${ }^{50}$ As a result, citizens of the host state may view refugees as depleting already limited resources, leading to hostility and even violence against refugee populations. ${ }^{51}$ Of additional concern, refugee populations tend to remain displaced for long period of time. Two-thirds of the world's refugees have been displaced for more than five years. ${ }^{52}$ Sovereignty-based conflicts are no exception, with refugees fleeing to states that may lack the capacity and infrastructure to host them.

Externalities of Civil Strife: Refugees As a Source of International Conflict, 52 AM. J. OF POL. SCI. 787, 789-90 (2008).

46. See Salehyan, supra note 45 , at 791 .

47. Id.

48. See Idean Salehyan \& Kristian Skrede Gleditsch, Refugees and the Spread of Civil War, 60 INTERNATIONAL ORGANIZATION 335, 343 (2006).

49. Indeed, such large influxes of refugees have been linked to destabilizing effects in the host state, such as environmental degradation and scarcity, radicalization, civil war spillover, and interstate tension and conflict. Furthermore, it has been posited that refugee flows, rather than being a mere externality of conflict, may actually catalyze conflict within and between states. Conflict between states may arise due to the presence of opposition leaders and fighters in refugee camps, which may prompt the home state to launch attacks against the camps within the territorial borders of the host state. Additionally, armed opposition groups within the refugee populations may seek out alliances with sympathetic local groups in the host state, thereby intensifying underlying intemal strife and conflict. The destabilizing impact of refugees on the host state is exacerbated by resource scarcity. For instance, the estimated 165,000 Sahrawi refugees living in Algeria rely exclusively on humanitarian assistance.

50. Refugees: The Numbers, U.N., available at http://www.un.org/en/globalissues/ briefingpapers/refugees/ (last visited Jan. 28, 2015); Global Appeal 2015 Update - Populations of Concern to UNHCR, UNHCR (2015), available at http://www.unhcr.org/546l e5ec3c.html (last visited Jan. 28, 2015).

51. See Salehyan \& Gleditsch, supra note 48, at 344; see Martin, supra note 45, at 333

52. Refugees: The Numbers, supra note 50. 
For instance, the conflict for separation between North and South Sudan resulted in hundreds of thousands of Sudanese fleeing the violence to neighboring states. ${ }^{53}$ As demonstrated by the experience of these refugees, those fleeing violent conflict in their home state may encounter additional threats to their safety or security in the host state. Sudanese refugees in Egypt became targets of violence and suffered a brutal crackdown by police when unarmed refugees protested outside the UN High Commissioner for Refugees' office in $2005 .{ }^{54}$ Similarly, Eritrean refugees who fled to Sudan during the Eritrean war for independence found themselves in overcrowded camps with limited access to food and vulnerable to the raging Sudanese conflict. ${ }^{55}$

Even seemingly latent sovereignty-based conflicts may risk sudden escalation and threaten regional stability if left unaddressed. For instance, the unresolved status of Western Sahara has significantly impacted neighboring Algeria, which currently houses up to 165,000 Sahrawi refugees. ${ }^{56}$ Furthermore, Algeria's support for the Sahrawi proindependence Polisario Front has created significant tensions with its neighbor Morocco. ${ }^{57}$ This instability is rooted in the international community's failure to set forth a workable framework for selfdetermination for Western Sahara's Sahrawis.

53. 2015 UNHCR country operations profile-Sudan, UNHCR (2015), available at $\mathrm{http} / / /$ www.unhcr.org/pages/49e483b76.html (last visited Jan. 28, 2015) (an estimated 100,000 fled to Kenya); UNHCR Egypt Fact Sheet, UNHCR (Jan. 2012), available at http://www.unhcr.org/ 4f4c956c9.html (last visited Jan. 28, 2015) (24,934 fled to Egypt); UNHCR Global Appeal-Uganda, UNHCR (2005), available at http://www.unhcr.org/41 ab28e7c.html (last visited Jan. 28, 2015) (172,000 fled to Uganda).

54. Abeer Allam \& Michael Slackman, 23 Sudanese Die as Egypt Clears Migrants' Camp, N.Y. TIMES (Dec. 31, 2005), available at http://www.nytimes.com/2005/12/31/international/africa/ 3 legypt.html (last visited Jan. 28, 2015); Sarah El Masry, A Marginalized Community: Sudanese Refugees in Egypt, DAILY NEwS EGYPT (Sept. 5, 2012), available at http://www.dailynewsegypt.com/ 2012/09/05/a-marginalised-community-sudanese-refugees-in-egypt/ (last visited Jan. 28, 2015).

55. The United States Committee for Refugees estimated that more than 380,000 Eritrean refugees were living in Sudan in the 1990s. U.S. Comm. for Refugees, Getting Home is Only Half the Challenge: Refugee Reintegration in War-Ravaged Eritrea, REF WORLD 5 (Aug. 2001), available at http://www.refworld.org/pdfid/3bc19092d.pdf (last visited Jan. 28, 2015); see Eritrea-Sudan: $A$ Forgotten Refugee Problem, IRIN (Dec. 3, 2009), available at http://www.irinnews.org/report/87300/ eritrea-sudan-a-forgotten-refugee-problem (last visited Jan. 28, 2015).

56. Western Sahara Territory: 2015 UNHCR Subregional Operations Profile-North Africa, supra note 49.

57. Egypt-Algeria Cooperation on W. Sahara Irks Morocco, WORLd BULLETIN (Jan. 3, 2015), http:/www.worldbulletin.net/news/152130/egypt-algeria-cooperation-on-w-sahara-irks-morocco (last visited Jan. 28, 2015); see generally Diplomacy Over Western Sahara: Morocco v Algeria, ECONOMIST (Nov. 4, 2010), available at http://www.economist.com/node/17421589 (last visited Jan. 28, 2015). 
Morocco annexed the territory in 1975 as Spain began to diminish its colonial rule. ${ }^{58}$ In 1976, the Polisario Front established the Sahrawi Arab Democratic Republic (SADR) and declared independence from Morocco. ${ }^{59}$ This declaration was followed by over a decade of armed conflict between Morocco and the Polisario Front, which ended with a UN-brokered ceasefire in $1991 .{ }^{60}$ The UN's plan for Western Sahara called for a transitional period during which the UN would oversee the ceasefire implementation as well as the preparations for a referendum on independence or unification with Morocco. ${ }^{61}$ However, twenty years later, the transitional period has yet to commence and the parties seem no closer to an agreement. ${ }^{62}$ Meanwhile, forty-seven states and the African Union maintain recognition of SADR. ${ }^{63}$ Multiple rounds of negotiations have yielded only nominal progress and younger Sahrawis are losing patience with the process and with the UN. ${ }^{64}$ If the parties cannot agree on a plan that would eventually allow the Sahrawis to vote on self-determination, some commentators argue the situation may devolve into a full-scale armed conflict. ${ }^{65}$ Considering King Mohammed VI of Morocco's statements that Western Sahara will remain part of Morocco "until the end of time," the

58. Human Rights and Freedom from State Tyranny: Country Studies-Morocco, DEMOCRACY WEB, available at http://www.democracyweb.org/rights/morocco.php (last visited Jan. 28, 2015).

59. Western Sahara/Algeria: Refugees Face Curbs on Rights, HuM. RTS. WATCH (Oct. 18, 2014), available at http:/www.hrw.org/news/2014/10/18/western-saharaalgeria-refugees-face-curbsrights (last visited Jan. 28, 2015).

60. U.N. Mission for the Referendum in Western Sahara (MINURSO)-Background, U.N.,

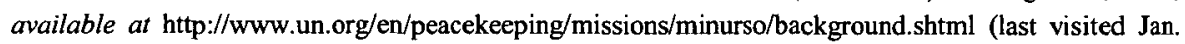
28,2015 ).

61. Id.

62. Natasha White, Conflict Stalemate in Morocco and Western Sahara: Natural Resources, Legitimacy and Political Recognition, 41 BRIT. J. MIDDLE E. STUD. 1, 7 (2014); U.N. Mission for the Referendum in Western Sahara, supra note 60; Sahara's Polisario Front Threatens New Armed Struggle, YAHOO! NEWS (Nov. 9, 2014), http://news.yahoo.com/saharas-polisario-front-threatensarmed-struggle-193148261.html (last visited Jan. 28, 2015).

63. Eighty-five states have recognized SADR, however, thirty-eight have since withdrawn or frozen their recognition. White, supra note 62 , at 6 .

64. See id. at 17; Larisa Epatko, Should Sahrawis Return to War with Morocco? 4 Young Refugees Speak Up, PBS.ORG (Oct. 25, 2013), http:/www.pbs.org/newshour/rundown/voices-ofsahrawi-refugees/ (last visited Jan. 28, 2015); Whitney Shefte, Could War Come Back to Western Sahara? Some of Algeria's Sahrawi Refugees Think So, WASH. PosT (Dec. 31, 2014), available at http://www.washingtonpost.com/blogs/worldviews/wp/2014/12/31/could-war-come-back-to-westernsahara-some-of-algerias-sahrawi-refugees-think-so/ (last visited Jan. 28, 2015).

65. Sahara's Polisario Front Threatens New Armed Struggle, supra note 62; Shefte, supra note 64 . 
current situation appears bleak without a serious change in course. ${ }^{66}$ As history indicates, without a specified mechanism by which to seek selfdetermination, frustrated groups are more likely to view fighting their way out as their only option.

In politically fragile states or regions, the very specter of sovereigntybased conflict can itself be destabilizing. The South Yemen independence movement threatens to further destabilize Yemen's attempts to form a sustainable federal democracy. ${ }^{67}$ The Southern Yemeni population has fed a continuous rumbling for independence since Yemen's unification in $1990 .^{68}$ The desire for independence is based on the sentiments of cultural separation and political disenfranchisement from the population and government in the north.

Similar to other sovereignty-based conflicts, the Southern Yemen movement has seen periods of violence and continues to promote a level of instability that creates a safe space for terrorists to flourish. Specifically, the continued instability and political discontent in the South offers an appealing environment for Al Qaeda of the Arabian Peninsula (AQAP) to build a stronghold. ${ }^{6}$ As AQAP's attacks during the Houthi uprising demonstrate, political upheaval provides a dangerous environment that AQAP is eager and able to exploit. ${ }^{70}$

Moreover, groups seeking to destabilize the status quo may take up the cause of self-determination to establish greater legitimacy and shore up support among their desired constituency. Although these groups may seek alternative ends entirely distinct from self-determination, the groups may nonetheless co-opt self-determination into their other destabilizing activities. For instance, the Congolese Resistance Patriots in the North Kivu province have claimed separatist goals for the ethnic Mai Mai

66. Sahara's Polisario Front Threatens New Armed Struggle, supra note 62.

67. Stephen Day, The Political Challenges of Yemen's Southern Movement, YEMEN: ON THE BRINK, (Carnegie Paper Series 2010), available at http://carnegieendowment.org/files/yemen south_movement.pdf (last visited Jan. 28, 2015).

68. See generally Unification of Yemen, 1990-Yemen History, AL-BAB (May 28, 2009), available at http://www.al-bab.com/yemen/unity/unify.htm (last visited Jan. 28, 2015).

69. See Al-Qa'ida in the Arabian Peninsula, NAT'L COUNTERTERRORISM CTR., available at http://www.nctc.gov/site/groups/aqap.html (last visited Jan. 28, 2015); Nadwa Al-Dawsari, Tribes and $A Q A P$ in South Yemen, ATL. COUNCIL (June 5, 2014), available at http://www.atlanticcouncil.org/blogs/menasource/tribes-and-aqap-in-south-yemen (last visited Jan. 28, 2015).

70. Tim Lister \& Paul Cruickshank, Al Qaeda Resurgent in Yemen Amid Political Turmoil, CNN (Oct. 17, 2014), available at http:/www.cnn.com/2014/10/15/world/meast/yemen-crisis/ (last visited Feb. 7, 2015). 
population in the region as a way to generate local support. ${ }^{71}$ Once activated, it is often difficult to contain the pull of the desire for selfdetermination. ${ }^{72}$

Extremist groups who carry out ethnic or religious based violence may seek to exploit the allure of self-determination by conducting their activities under the guise of a sovereignty-based conflict. Although they are known primarily for kidnappings and bombings, Nigeria's Boko Haram also espouses aims of establishing an Islamic state within Nigeria. ${ }^{73}$ Their activities against the Nigerian government have caused great instability and cost over 5,000 lives. ${ }^{74}$ Similarly, the extremist organization known as the Islamic State has waged a destabilizing and deadly war in Iraq and Syria with the aim of creating its own state. ${ }^{75}$ The group has engaged in countless human rights violations, from forced marriages to mass killings of civilians, including children. ${ }^{76}$ These crimes are committed under the partial mantra of self-determination for the Sunni populations in Iraq and Syria, and do receive some local support on this basis. ${ }^{77}$

\section{FALSE SECURITY IN ECONOMIC PROSPERITY AND REGIONAL INTEGRATION: EUROPE'S FAILED SELF-DETERMINATION POLICY}

Even integrated regional systems, such as the European Union (EU), continue to be beset by non-violent sovereignty based conflicts grounded in

71. Always on the Run, HuM. RTS. WATCH (Sept. 14, 2010), http:/www.hrw.org/es/node/ 92770/section/3 (last visited Feb. 7, 2015).

72. See Luc Torres et al., The Separatist Map of Africa, THE GuARDIAN (Sept. 6, 2012), available at http://www.theguardian.com/world/interactive/2012/sep/06/africa-map-separatistmovements-interactive; DRC: Who's Who Among Armed Groups in the East, IRIN (June 15, 2010), available at http://www.irinnews.org/report/89494/drc-who-s-who-among-armed-groups-in-the-east (last visited Feb. 7, 2015); Democratic Republic of Congo's Key Armed Groups, THE GLOBAL PosT (July 17, 2013), available at http://www.globalpost.com/dispatch/news/afp/130717/democraticrepublic-congos-key-armed-groups (last visited Feb. 7, 2015).

73. Mohammed Aly Sergie \& Toni Johnson, Boko Haram, COUNCIL on FoREIGN RELATIONS (Oct. 7, 2014), available at http://www.cfr.org/nigeria/boko-haram/p25739 (last visited Feb. 7, 2015).

74. Id.

75. See Joe Boyle, Islamic State and the Idea of Statehood, BBC.COM (Jan. 5, 2015), available at http://www.bbc.com/news/world-middle-east-30150681 (last visited Feb. 7, 2015); see Adam Chandler, Even ISIS Needs a Bank, THE ATLANTIC (Jan. 5, 2015), available at $\mathrm{http}: / /$ www.theatlantic.com/international/archive/2015/01/islamic-state-starts-islamic-bank/384211/ (last visited Feb. 7, 2015).

76. Iraq: Forced Marriage, Conversion for Yezidis, HuM. RTS. WATCH (Oct. 12, 2014), available at $\mathrm{http}: / / \mathrm{www} . \mathrm{hrw} . \mathrm{org} / \mathrm{news} / 2014 / 10 / 11 / \mathrm{iraq}$-forced-marriage-conversion-yezidis (last visited Feb. 7, 2015).

77. Boyle, supra note 75 . 
self-determination. The very existence of the EU was partly intended to quell self-determination movements by ushering in an era of postsovereignty, based on economic prosperity and regional integration. However, Europe nevertheless faces increasing calls for self-determination and independence by sub-state entities. ${ }^{78}$

As Christopher K. Connolly explains, the belief that the creation of the EU would lessen the appeal of sovereignty for groups seeking selfdetermination was partially premised on the idea that regions composed of local governments would replace states as the predominant actors in the EU. ${ }^{79}$ However, the rise of regions never came to pass and states remain the primary actors within the EU political framework. ${ }^{80}$ Indeed, only sovereign states may participate in the governing institutions of the EU, including the European Council and the European Parliament.

As Connolly observes, the operation of EU institutions has a "contradictory influence" on sub-state groups seeking self-determination. ${ }^{81}$ By granting a degree of autonomy and influence to regions, the EU may lessen the desire of sub-state groups for full independence if they can participate in EU affairs through regional mechanisms. ${ }^{82}$ However, the ability of sub-state actors to prove their capacity to operate independently of their parent state may embolden their self-determination aspirations. ${ }^{83}$ Furthermore, the continued limitation of full participation in EU institutions to sovereign states may create greater incentives for these movements to seek sovereignty for themselves. ${ }^{84}$ The confusion regarding under what circumstances newly independent states could accede to the EU, serves only to compound these issues. ${ }^{85}$ While acknowledging that each movement for self-determination is unique, Connolly argues that the time has come for the EU to clarify its position on the accession of newly sovereign states. ${ }^{86}$ It also appears that the belief that economic integration is sufficient to quell the desire for self-determination is misplaced. Rather, perceptions of economic unfairness stemming from the need for resource distribution, which accompanies integration, fuel self-determination desires.

78. See Christopher K. Connolly, Independence in Europe: Secession, Sovereignty, and the European Union, 24 DUKE J. COMP. \& INT'L L. 51, 53-54 (2013).

79. See id. at $79-81$.

80. Id.

81. Id. at $83-84$.

82. Id.

83. Connolly, supra note 78 , at 84 .

84. Id. at 83-84.

85. Id. at 84 .

86. See id. 
The EU unfortunately has failed to develop a coherent policy in response to self-determination movements both within and outside its borders. For a brief period of time in the early 1990s, the EU, then the European Community (EC), attempted to develop such a policy. During the breakup of the former Yugoslavia, the European Community established the Badinter Arbitration Commission to determine the merit of claims for independence. ${ }^{87}$ The Commission's first opinion determined that Yugoslavia was "in the process of dissolution," 88 prompting the EC to adopt two declarations, one of which was a common recognition policy intended to assist member states in deciding whether to recognize states emerging from the breakup of Yugoslavia. ${ }^{89}$ The policy indicated the willingness of EC member states to recognize emerging states provided that they demonstrated that they possessed a "democratic basis, had accepted the appropriate international obligations and had committed themselves in good faith to a peaceful process and to negotiations." ${ }^{.90}$

The failure of member states to act in concert and abide by the common recognition policy ultimately forced many member states into recognizing states that they believed had not met the requisite qualifications enumerated in the policy. ${ }^{91}$ Specifically, Germany's unconditional recognition of Slovenia and Croatia prompted many member states to recognize these states over the EU's own objections for the sake of maintaining a common policy. ${ }^{92}$

Europe has since avoided developing a common, or even coherent, policy on recognition, particularly for self-determination movements within the EU's borders. Rather, the EU is currently treating the issue of selfdetermination as an internal matter-a mistake that risks cracking the continent's increasingly delicate unity. ${ }^{93}$

87. See Alain Pellet, The Opinions of the Badinter Arbitration Committee A Second Breath for the Self-Determination of Peoples, 3 EUR. J. INT'L L. 178 (1992), available at http://ejil.org/pdfs/3/1/1175.pdf (last visited Apr. 2, 2015).

88. Id.

89. Declaration on the "Guidelines on the Recognition of New States in Eastern Europe and in the Soviet Union”, Dec. 16, 1991, 31 I.L.M. 1486-87 (1992); see Diane F. Orentlicher, Separation Anxiety: International Responses to Ethno-Separatist Claims, 23 YALE J. INT'L L. 1, 78 (1998).

90. Declaration on the "Guidelines on the Recognition of New States in Eastern Europe and in the Soviet Union," supra note 89, at 1486-87.

91. See Orentlicher, supra note 89 , at 67.

92. Id. at 68 .

93. Paul Williams \& Roushani Mansoor, How the Voters of Catalonia May Change Europe, ATL. CouNCIL (Jan. 16, 2014), available at http://www.atlanticcouncil.org/blogs/new-atlanticist/howthe-voters-of-catalonia-may-change-europe (last visited Feb. 7, 2015). 
Cyprus and Kosovo illustrate the inconsistencies and shortcomings of the EU's "non-policy" on self-determination. In Cyprus, the EU's failure to deal with Northern Cyprus has created a half-member EU state in which all Cypriots are EU citizens, but EU laws and regulations govern only half the country. The EU's disjointed policy has also impacted Kosovo, which remains in international limbo. Kosovo is recognized by 103 countries, excluding five EU member states, yet it is in the final stages of obtaining a stabilization and integration agreement with the EU. ${ }^{94}$ Kosovo is a member of the World Bank and IMF, ${ }^{95}$ but not the United Nations. ${ }^{96}$

The continent's phobia of self-determination and its lack of any cohesive approach to newly independent states leaves it ill-prepared to address emerging self-determination movements within the EU, which will strain the very foundation of Europe. ${ }^{97}$ Nowhere was this more evident than in the European Commission's initial refusal to officially comment on the status of an independent Scotland, followed by inconsistent comments and signals. ${ }^{98}$ For example, Commission President Jose Manuel Barosso declared in February 2014 that it would be "very difficult, if not impossible" for Scotland to join the EU. ${ }^{99}$ However, the Commission failed to clarify these statements during the lead up to the elections. ${ }^{100}$

This lack of transparency led to significant speculation and posturing on both sides of the issue. With no clear signal from the Commission, Spain was free to threaten that it would block Scottish membership in the EU. On the other hand, the leadership of the Scottish referendum promised

94. Stabilization and Association Agreement Initialed, REPUBLIC OF KOS. MINISTRY OF EUROPEAN INTEGRATION (July 25, 2014), available at http://www.mei-ks.net/?page=2,5,1011 (last visited Feb. 7, 2015).

95. See Lundrim Aliu \& Michael Jones, Kosovo Joins World Bank, WORLD BANK (2013), available at http://web.worldbank.org/WBSITE/EXTERNALCOUNTRIES/ECAEXT/0,print:Y is CURL:Y contentMDK:22230081 menuPK:258604 pagePK:2865106 piPK:2865128 theSitePK:2585 99,00.html (last visited Feb. 7, 2015).

96. See generally Member States of the United Nations, UN.ORG, http://www.un.org/en/members/ (last visited Feb. 7, 2015).

97. How the Voters of Catalonia May Change Europe, supra note 93.

98. MEPs Could Block Scotland's EU Membership if it Pushes for Euro Opt-Out, EURACTIVE (Sept. 17, 2014), http://www.euractiv.com/sections/uk-europe/meps-could-block-scotlands-eumembership-if-it-pushes-euro-opt-out-308434 (last visited Feb. 7, 2015).

99. Independent Scotland's EU Membership Would be 'Very Difficult, if not Impossible' Says Jose Manuel Barroso, HuFFngtonPost.COM (Feb. 16, 2014), available at http://www.huffingtonpost.co.uk/2014/02/16/independent-scotlands-eu-_n_4797487.html (last visited Feb. 7, 2015).

100. See MEPs Could Block Scotland's EU Membership if it Pushes for Euro Opt-Out, supra note 98 . 
that accession could be fast-tracked in as little as eighteen months. ${ }^{101}$ The United Kingdom remained silent. With their EU membership still uncertain, the Scots ultimately voted against independence on September 18,2014 , by a margin of 10.6 percent. ${ }^{102}$ By failing to establish a strategic framework for managing calls for independence, the EU is ignoring a continually relevant issue that has the potential to breed further uncertainty and instability in the region.

Once the Scottish referendum was put to rest, the EU immediately faced another self-determination crisis-this time in Catalonia. On November 9, 2014, almost 2,000,000 Catalonian voters turned out to participate in a non-binding referendum for independence, eighty percent of those who voted favored independence from Spain. ${ }^{103}$ The referendum was approved by the Catalonian Parliament on September 27, 2014, and was originally slated to be a binding vote similar to the one held in Scotland. ${ }^{104}$ In the run up to the referendum, Catalonian regional Premier Atur Mas set forth a legal basis for a binding referendum. ${ }^{105}$ The Spanish Prime Minister, Rajoy, however, vowed to use the Spanish courts to block what he considered an unconstitutional vote. ${ }^{106}$ Within two days of the announcement of the referendum date, the Spanish government filed a

101. Simon Johnson \& Bruno Waterfield, Spanish Prime Minister Gives EU Warning to Scots, TELEGRAPH.Co.UK (Sept. 17, 2014), available at http:/www.telegraph.co.uk/news/uknews/scottishindependence/11101758/Spanish-Prime-Minister-gives-EU-warning-to-Scots.html (last visited Feb. 7, 2015).

102. Simon Johnson, Alex Salmond Says Scottish Independence 'in My Lifetime', TELEGRAPH.CO.UK (Nov. 12, 2014), available at http://www.telegraph.co.uk/news/politics/ SNP/1 1225071/Alex-Salmond-says-Scottish-independence-is-not-dead.html (last visited Feb. 7, 2015).

103. The referendum posed two questions to the Catalonian people. The first asked whether Catalonia should become a state. The second asked whether the state should be independent. Eighty percent of voters answered affirmatively to both questions. About ten percent voted "yes" to the first question only, and 4.5 percent voted "no" to both questions. Catalonia Vote: $80 \%$ Back Independence - Officials, BBC.cOM (Nov. 10, 2014), available at http:/www.bbc.com/news/world-europe-29982960 (last visited Mar. 2, 2015); Voting in Their Hearts, ECONOMIST (Nov. 15, 2014), available at http://www.economist.com/news/europe/21632479-catalan-vote-november-9th-will-do-little-resolvefuture-either-region-or (last visited Feb. 7, 2015); Catalonia Profile, BBC.COM (Jan. 15, 2015) http://www.bbc.com/news/world-europe-20345073 (last visited Feb. 7, 2015).

104. Tom Burridge, Catalonia president signs independence referendum decree, ВВС.СОМ (Sep. 27, 2014), available at http://www.bbc.com/news/world-europe-29390774 (last visited Feb. 7, 2015).

105. See id.

106. Fiona Govan, Spain blocks Catalonia referendum on Independence, TELEGRAPH.Co.UK (Sept. 29, 2014), available at http://www.telegraph.co.uk/news/worldnews/europe/spain/11129376/ Spain-blocks-Catalonia-referendum-on-independence.html (last visited Feb. 7, 2015). 
request for the Constitutional Court to declare the referendum illegal. ${ }^{107}$ On the same day, the Constitutional Court unanimously agreed to hear the challenge, and automatically suspended the referendum until its legality could be assessed. ${ }^{108}$ As a consequence Catalonia held the non-binding referendum. ${ }^{109}$

Notably a major impetus for the referendum on independence was that the Constitutional Court had quashed an earlier effort for a more mild form of self-determination in the form of greater autonomy. ${ }^{110}$ In 2006, Catalonians voted in favor of a Statute of Autonomy that, among other provisions, declared Catalonia a "nation."111 Spanish Prime Minister Rajoy's party challenged the statute's constitutionality before the Constitutional Court, which found several articles, including the declaration of a Catalonian "nation," to be unconstitutional. ${ }^{112}$

In light of the non-binding referendum, and the Constitutional Court challenge, Catalonian leadership plans to call for expedited parliamentary elections. ${ }^{113}$ In the wake of the November $9^{\text {th }}$ referendum, the elections are expected to substantially strengthen the majority of the pro-independence parties, thereby operating as a de facto independence referendum. ${ }^{114}$

In addition, less than a month after the referendum, the Catalonian leadership outlined a plan to achieve independence within eighteen

107. Ashifa Kassam, Catalonia Independence Referendum Halted by Spain's Constitutional Court, THE GuARDIAN (Sept. 29, 2014), available at http://www.theguardian.com/world/2014/sep/29/ catalonia-independence-referendum-spain-court-vote (last visited Feb. 7, 2015).

108. Id.

109. See Ashifa Kassam, Catalans Vote in Symbolic Referendum on Independence in Defiance of Madrid, THE GUARDIAN (Nov. 17, 2014), http:/www.theguardian.com/world/2014/nov/09/catalansvote-symbolic-referendum-independence-catalonia-madrid (last visited Feb. 7, 2015).

110. See Connolly, supra note 78 , at 58.

111. Fiona Govan, Catalans Vote for Greater Autonomy in Referendum, TELEGRAPH.Co.UK (June 19, 2006), available at http://www.telegraph.co.uk/news/worldnews/europe/spain/1521706/ Catalans-vote-for-greater-autonomy-in-referendum.html. (last visited Feb. 7, 2015).

112. See Matt Moffett, Spain's Parliament Rejects Catalonia Bid for Independence Vote, WALL ST. J. (Apr. 8, 2014), http://www.wsj.com/articles/SB1000142405270230481900457948958108 1862634 (last visited Feb. 7, 2015).

113. Raphael Minder, Catalonia's Leader Plays Down Talk of Secession Crisis, N.Y. TIMES (Oct. 8, 2014), available at http://www.nytimes.com/2014/10/09/world/europe/catalonias-leader-playsdown-talk-of-secession-crisis.html (last visited Feb. 7, 2015).

114. See generally Rafael Minder, Catalonia Cancels Vote to Secede From Spain, but Calls for Nonbinding Ballot, N.Y. TIMES (Oct. 14, 2014), available at http://www.nytimes.com/2014/ 10/15/world/europe/catalonia-cancels-referendum-on-independence-in-november.html (last visited Feb. $7,2015)$. 
months. ${ }^{115}$ As a first step, the plan invites political parties to adopt a common platform supporting independence. ${ }^{116}$ While the parties have not formally agreed, the two largest Catalonian political parties plan to continue to negotiate through the spring of 2015. ${ }^{17}$ In the interim, Spain has adopted a hardline position against Mr. Mas and his deputies by filing criminal charges against them for their facilitation of the nonbinding vote. ${ }^{118}$

Despite the potentially destabilizing impact of this ongoing dispute within Spain, the domestic legal debate may be largely irrelevant to the EU. If Catalonians eventually choose independence, they will seek international recognition as an independent state based on the will of the people, not on provisions of the Spanish constitution. ${ }^{119}$ As the International Court of Justice (ICJ) noted when reviewing the legality of Kosovo's declaration of independence, there is no international legal bar against a sub-state entity declaring independence. ${ }^{120}$

Without a coherent and cohesive approach to these movements, the EU has placed itself in an impossible and precarious position. If the EU were to consider recognizing Catalonia, this action could encourage further referenda in Belgium, Cyprus, Slovakia, Romania, and possibly Italy, raising opposition from these members. ${ }^{121}$

However, if the $\mathrm{EU}$ denies recognition to Catalonia, this may generate a frozen economic conflict in the core of Europe that would drain political capital and economic resources from an economically fragile Spain. This frozen economic conflict will also create a "state," with the Euro as its currency and seven million Catalonians that could retain their EU citizenship while living outside the EU. ${ }^{122}$ Furthermore, in many European states, non-recognition would be perceived as anti-democratic. Such a move would be extremely difficult to justify, given that nearly two-dozen

115. Julian Toyer, Catalonia Moves Closer to Early Election as Dialogue Hopes Fade, REUTERS (Nov. 26, 2014), http://www.reuters.com/article/2014/11/26/us-spain-cataloniaidUSKCNOJA1 YU20141126 (last visited Feb. 7, 2015).

116. Id.

117. See generally id.

118. Id.

119. How the Voters of Catalonia May Change Europe, supra note 93.

120. Accordance with International Law of the Unilateral Declaration of Independence in Respect of Kosovo, Advisory Opinion, 2010 I.C.J. 52 (July 22), available at http://www.icjcij.org/docket/files/141/15987.pdf (last visited Feb. 7, 2015).

121. How the Voters of Catalonia May Change Europe, supra note 93.

122. Id. 
states have achieved recognition by EU member states in the past twentyfive years. ${ }^{123}$

As the recent referenda within EU borders demonstrate, relative economic prosperity and regional integration do not guarantee that sub-state entities will not seek greater internal autonomy, or even independence. Rather, the EU remains a system built upon states and, as such, provides an incentive for these movements to pursue self-determination. ${ }^{124}$ With up to twenty-five "significant" separatist movements across Europe, Catalonia and Scotland are certainly not the last referenda that the will EU face. ${ }^{125}$

\section{SOVEREIGNTY-FIRST AND THE FAILURE TO ESTABLISH VIABLE NEW STATES}

The international community's prevailing preference for sovereignty above all else not only hampers the development of pragmatic policies but also threatens regional and global stability. Even under circumstances wherein a parent state and a sub-state entity seeking independence agree to a step-wise process of independence, the international community's hesitant stance threatens to prevent the implementation of transitional mechanisms and the creation of institutions necessary to create a viable new state.

For instance, the 2005 Comprehensive Peace Agreement (CPA) for Sudan envisioned a six-year interim period during which the Government of Sudan and the Sudanese People's Liberation Movement (SPLM) would share power while contemplating continuing unity or separation into two independent states. ${ }^{126}$ The parties agreed that, at the end of the interim period, the people of South Sudan would take part in a referendum to decide whether to remain part of Sudan or become independent. ${ }^{127}$ Although the agreement provided for devolution of power to the South during the interim period and recognition of the South's right to self-

123. Id.

124. See Connolly, supra note 78.

125. Christopher J. Borgen, From Kosovo to Catalonia: Separatism and Integration in Europe, 2 GJIL 997, 1010 (2010), available at http://www.gojil.eu/issues/23/23_article_borgen.pdf (last visited Feb. 7, 2015).

126. Comprehensive Peace Agreement, Government of Sudan and the Sudan People's Liberation Movement/Army, Ch. I, art 2.1, July 20, 2002, available at http://peacemaker.un.org/ sites/peacemaker.un.org/files/SD_060000_The\%20Comprehensive $\% 20 \mathrm{Peace} \% 20 \mathrm{Agreement.pdf,} \mathrm{(last}$ visited Feb. 7, 2015).

127. Comprehensive Peace Agreement, Government of Sudan and the Sudan-People's Liberation Movement/Army, Ch. II, art 2.5, May 26, 2004; see Anthony J. Christopher, Session and South Sudan: An African Precedent for the Future, 93 S. AFR. GEOGRAPHICAL J. 125, 128 (2011). 
determination, it also required that the parties pursue measures in accordance with the goal of "[making] unity attractive" to the South. ${ }^{128}$

The CPA was ultimately not successful in making unity attractive to the South, partially due to the North's refusal to fully implement the terms of the agreement that called for devolution of power to the South. ${ }^{129}$ It soon became clear that the North never intended to grant greater power and autonomy to the South, nor planned to allocate meaningful posts within the central government to southern leaders. ${ }^{130}$ Fearing that it would undermine efforts to promote unity, the international community also failed to contribute to building South Sudan's institutional capacity during the interim period. ${ }^{131}$ Rather than planning for a scenario in which the South attained independence, the self-determination-averse and sovereignty-first driven international community opted to focus exclusively on making unity attractive to the South. ${ }^{132}$

This decision ultimately did a great disservice to South Sudan, whose citizens voted nearly unanimously for independence in 2011. ${ }^{133}$ During the interim period, the stalled implementation efforts left the South without the necessary institutions to support the world's newest democracy. ${ }^{134}$ Rather than laying the groundwork for a functional democracy, the five-year period became a missed opportunity for a peaceful transition to independence. Without the necessary framework, underlying divisions in the newly independent South Sudan soon boiled over into large-scale violence. In just over a year of violence the death toll reached nearly $100,000 . .^{135}$

128. Comprehensive Peace Agreement, Government of Sudan and the Sudan People's Liberation Movement/Army, supra note 126.

129. See generally Lovise Aalen, Making Unity Unattractive, 15 CIV. WARs 173, 187 (2013); Aleksi Ylonen, Building a State Without the Nation? "Peace-Through-Statebuilding" in Southern Sudan, 2005-2011, 33 UNISCI 13, 21-22 (2013).

130. Aalen, stupra note 129 , at 187.

131. Id.

132. TERENCE MCNAMEE, THE FIRST CRACK IN AFRICA'S MAP? SECESSION AND SElFDETERMINATION AFTER SOUTH SUdAN 12 (2012).

133. Khalid Mustafa Medani, Strife and Secession in Sudan, 22 J. OF DEMOCRACY 135, 135 (2011).

134. See Ylonen, supra note 129, at 28-29.

135. Compare Peter Martell, 50,000 Dead and Not Counting: South Sudan's War Dead, AGENCE FRANCE-PRESSE (Nov. 16, 2014), available at http://www.msn.com/en-ph/news/ newsworld/50000-and-not-counting-south-sudans-war-dead/ar-BBdY9Zs (last visited Feb. 7, 2015). 


\section{LOOKING FORWARD: UTILIZING EARNED SOVEREIGNTY AS A STRATEGIC FRAMEWORK FOR MANAGING SELF-DETERMINATION BASED CONFLICTS}

Of the seventy active sovereignty-based conflicts around the world, nearly all could benefit from a strategic framework that engenders peaceful resolution to conflict through a clear process that involves some degree of enhanced self-government, international engagement, and robust institution building. Unfortunately, the status quo predominantly grants independence to entities that fight their way to independence, which perpetuates violence and instability. ${ }^{136}$

Recent instances of state practice provide some hope that states beset by sovereignty-based conflicts are ready to move from the sovereignty-first approach and consider more flexible responses to achieve greater selfdetermination. For example, when the British faced the Scottish independence movement, they chose a proactive approach, accepting the call for a referendum, and ultimately aiming to make unification attractive by offering devolution max, full fiscal autonomy, during the final days of the campaign. ${ }^{137}$ Similarly, in Canada, the Supreme Court determined that Quebec did indeed have the legal right to enter into independence negotiations, although it could not seek independence unilaterally. ${ }^{138}$ The Canadian government then negotiated a referendum, which, like the Scottish referendum, ended with the population deciding to remain unified. ${ }^{139}$

Further illustrations of proactive state practice regarding selfdetermination are seen in Serbia and Montenegro, and Bougainville. In Serbia and Montenegro, the international community worked closely with the parties to broker a three-year treaty that created space for both parties to deescalate tensions and build institutions in preparation for possible independence. Montenegro's commitment to peace and stability was rewarded by recognition from the EU and the United States as well as the broader international community. This recognition demonstrates how the international community can contribute and reward peaceful actors. In Bougainville's fight for independence from Papua New Guinea, the parties relied upon an earned sovereignty approach, which allowed for a ten-to-

136. See ASIL Speech, supra note 15.

137. See David Cameron defends decision to allow Scottish independence vote, THE GUARDIAN (May 8, 2014), http:/www.theguardian.com/politics/2014/may/08/david-cameron-defends-decisionscottish-independence-referendum (last visited Jan. 29, 2015).

138. See Reference re Secession of Quebec, [1998] S.C.R. 217 (Can.).

139. See Gerald L. Gall, Québec Referendum (1995) (Aug. 21, 2013), http:/www.thecanadianencyclopedia.ca/en/article/quebec-referendum-1995/ (last visited Feb. 7, 2015). 
fifteen-year period of institution building and sharing of sovereign authority prior to a vote on possible independence. ${ }^{140}$

Building upon these recent demonstrations of state practice and formulating a cohesive and definitive path forward for future selfdetermination movements would create some certainty when groups seek to exercise their right of self-determination. In the absence of such an approach, each referendum is treated as a discrete event. Catalonia and Scotland illustrate that regional integration is not a panacea for the question of self-determination. Indeed, it may be that integrated regions would benefit greatly, if not most, from a cohesive policy that manages selfdetermination and the possible outcome of independence, head on.

Europe needs to create a strategic framework to address any future votes for independence. An initial step would be to place the decision for EU accession in the hands of the parent state. In the case of Scotland, this framework would have allowed the UK to usher Scotland through the process for EU accession without the threat of a Spanish veto.

Catalonia, however, would most likely be shutout of the EU following independence. Indeed, the Spanish government has made it known that, from its perspective, a right to self-determination does not equate with a right to full independence. ${ }^{141}$ Thus, the EU also must develop a parallel framework that can be implemented in the event that that the parent state vetoes accession. In crafting such an approach, the EU would likely need to consider a number of factors, such as the economic interests of the emerging state and the EU, as well as the fate of the current EU residents who face disenfranchisement if the new state is barred from accession.

Sub-state entities that are proactively given the opportunity to exercise their self-determination in a meaningful way, surprisingly often choose unification, as seen in Quebec and Scotland. ${ }^{142}$ However, states with a long history of violent resistance for the sake of realizing self-determination may require a more structured framework. For states emerging from conflict or

140. Bougainville Peace Agreement, Papua N.G.-Bougainville (Aug. 30, 2001), available at $\mathrm{http} / /$ www.usip.org/sites/default/files/file/resources/collections/peace_agreements/bougain_20010830.p df (last visited Feb. 7, 2015).

141. Borgen, supra note 125.

142. See Quebec History, MarianaPolis College (Aug. 23, 2000), http://faculty.marianopolis.edu/c.belanger/quebechistory/stats/1980.htm (last visited Mar. 2, 2015) (Quebec's first referendum vote took place in 1980 , resulting in a $59.5 \%$ to a $40.5 \%$ vote in favor of not seeking independence. In 1995 the Quebecers had another opportunity to vote for independence, however once again the vote was not successful. Similarly in Scotland, the referendum vote also did not receive the requisite number of votes); see also Scottish Referendum: Scotland Votes 'No' to Independence, BBC.COM (Sept. 19, 2014), available at http://www.bbc.com/news/uk-scotland29270441 (last visited Feb. 7, 2015). 
for parties still actively trying to fight their way out, the earned sovereignty model provides a framework for managing self-determination by incentivizing a cessation of hostilities to defuse the situation.

\section{CONCLUSION}

In both conflict and post-conflict states, the international community should consider applying an earned sovereignty approach as a vital component of a coherent means of addressing self-determination. History has demonstrated that violence in independence movements begets more violence. Earned sovereignty has proven successful in Serbia and Montenegro, East Timor, Northern Ireland and Bougainville. ${ }^{143}$ The earned sovereignty approach can easily be modified to apply in non-violent sovereignty disputes.

The original earned sovereignty approach provides for a three-pronged framework to resolving a sovereignty-based conflict: (1) shared sovereignty, (2) institution building, and (3) a determination of final status.

The three elements offer a flexible approach to resolving sovereigntybased conflicts. The first element, shared sovereignty, is a means of deescalating tensions and allowing parties to gain trust and build confidence in the conflict resolution process. The second element is institution building, which allows the international community to assist all parties to set up structures for governance and economic and political development. The third element allows parties to make a final determination by either maintaining the status quo, increasing autonomy, or granting independence. The ultimate determination can be realized in a number of ways, but often a referendum or negotiation between the state and the sub-state has proven most effective.

The earned sovereignty approach also includes three optional elements. The first optional element is phased sovereignty, which provides for the gradual accumulation of sovereign authority by the sub-state entity. The second optional element is conditional sovereignty, which prescribes benchmarks that the sub-state entity may meet before the ultimate determination on sovereignty is made. Undoubtedly, the creation of benchmarks must be handled delicately and efforts must be made to ensure that benchmarks are realistic, fair, and not skewed to favor unification. ${ }^{144}$ To promote fairness, the international community should include the substate entity in the creation of benchmarks and narrowly tailor benchmarks

143. Williams \& Pecci, supra note 6, at 349 n.10.

144. See generally Bemhard Knoll, From Benchmarking to Final Status? Kosovo and The Problem of an International Administration's Open-Ended Mandate, 16 EUR. J. INT'L L. 637, 639-41 (2005). 
to fit the nuanced needs of the would-be state. The third optional element is constrained sovereignty, which applies limitations on the sovereign authority and functions of the new state. ${ }^{145}$

To create a strategic framework for managing self-determination movements, the international community should work in tandem with state and sub-state entities to tailor earned sovereignty to the particularities of the situation. One suitable evolution would be to include greater focus on managing self-determination movements both internally and externally: a so-called dual approach. Applying a dual approach to earned sovereignty provides flexibility for the parent-state and sub-state entity to manage the nuanced concerns of shared autonomy or complete independence, while also allowing some management responsibilities to be allocated to the international community.

In the dual approach to earned sovereignty, the initial examination should begin at the domestic level. The purpose of beginning the management process at the domestic level is three-fold. First, creating a strategic framework that initially begins at the domestic level allows the process of managing self-determination to give deference to the existing rule of law mechanisms or other democratic processes in the state. These mechanisms may include appealing to the highest courts, or conducting a non-binding referendum on the question of self-determination. In instances where a state does not have established rule of law or democratic processes, the sub-state entity's efforts to peacefully engage the existing government in a dialogue regarding self-determination are sufficient and should constitute a good faith effort.

Second, beginning the management processes domestically allows for both the parent-state and the sub-state entity to create a portfolio of good faith efforts to engage the other party, ultimately enhancing the potential likelihood of reaching a consensus. In some instances, good faith efforts may take the form of a national dialogue, where participants can engage the parent-state and discuss the self-determination movement in a meaningful way. Other good faith efforts may take the form of the parent-state offering the sub-state entity greater political autonomy.

Third, starting the process domestically allows the parent-state and sub-state entity to take the lead and manage the process before the international community becomes involved. By beginning the process domestically, they can each take stock of the institutions, processes, and initiatives that must be developed or initiated for a successful separation or potential unification. Essentially, parties can begin to increase capacity for institution building, and decide on benchmarks for earned sovereignty that

145. See Williams \& Pecci, supra note 6, at 349. 
address the specific needs and consider the bargaining positions of each party.

The dual approach to earned sovereignty should also include responsibilities for the international community. Proactivity should be the primary responsibility of the international community when managing selfdetermination in the dual approach framework. The international community must be proactive because self-determination movements quickly become deadly. When it is apparent that a sovereignty-based dispute is arising, a duty should arise to proactively engage both parties. This proactive engagement by the international community should take the form of the traditional earned sovereignty framework, ${ }^{146}$ and should work in cooperation with domestic efforts to reach a consensus.

Earned sovereignty typically develops as part of the peace process after a sovereignty-based conflict; however it can be applied in non-violent sovereignty-based disputes as a management mechanism. ${ }^{147}$ The international community may be best suited to oversee the management mechanism and should offer assistance to all states engaged in sovereigntybased disputes. Input by both parties during all stages will ultimately make management successful.

Self-determination should be managed using a dual approach of both domestic and international management. This dual approach may be used as a starting point for a more comprehensive strategic framework for the

146. Williams \& Pecci, supra note 6, at 349.

147. See Paul R. Williams, Earned Sovereignty: The Future of Sovereignty-Based Conflict Resolution, 40 DENV. J. INT'L L. \& POL'Y 128 (2012); Grace Bolton and Gezim Visoka, Recognizing Kosovo's independence: Remedial secession or earned sovereignty?, South East European Studies at Oxford, Occasional Paper No. 11/10 (Oct. 2010), available at http:/www.sant.ox.ac.uk/seesox/pdf/ RecognizingKosovosindependence.pdf (last visited Feb. 7, 2015); Philip S. Hadji, The Case for Kurdish Statehood in Iraq, 41 CASE W. RES. J. INT'L L. 513 (2009); Nathan P. Kirschner, Making Bread from Broken Eggs: A Basic Recipe for Conflict Resolution Using Earned Sovereignty, 28 WHITTIER L. REV. 1131 (2007); Paul R. Williams \& Francesca Jannotti Pecci, Earned Sovereignty: Bridging the Gap Between Sovereignty and Self-Determination, 40 STAN. J. INT'L L. 347 (2004); Karen Heymann, Earned Sovereignty for Kashmir: The Legal Methodology to Avoiding A Nuclear Holocaust, 19 AM. U. INT'L L. REV. 153, 153 (2003); Paul R. Williams, Michael P. Scharf \& James R. Hooper, Resolving SovereigntyBased Conflicts: The Emerging Approach of Earned Sovereignty, 31 DENV. J. INT'L L. \& POL'Y 349 (2003); Michael P. Scharf, Earned Sovereignty: Juridical Underpinnings, 31 DENV. J. INT'L L. \& POL'Y 373 (2003); RALPH WILDE, INTERNATIONAL TERRITORIAL ADMINISTRATION: HOW TRUSTEESHIP AND The Civilizing Mission Never Went Away (2008); Philip S. Hadji, The Case for Kurdish Statehood in Iraq, 41 CASE W. RES. J. INT'L L. 513 (2009); Yaniv Voller, Kurdish Oil Politics in Iraq: Contested Sovereignty and Unilateralism, 20 MIDDLE EAST POL. 68 (2013); Nina Caspersen, Separatism and Democracy in the Caucasus, in SURVIVAL 113 (Vol. 50, no. 4, 2008); Yaniv Voller, Countering Violence Against Women in Iragi Kurdistan: State-Building and Transitional Advocacy, 46 INT'L J. MIDDle EAST STUD. 351 (2014); Nina Caspersena, Playing the Recognition Game: External Actors and De Facto States, 44 THE INT'L SPECTATOR: ITALIAN J. INT'L AFFS. 47 (2009). 
international community to successfully manage sovereignty-based conflicts. When international oversight is needed, assistance should be given freely and proactively. If the international community includes both the parent-state and sub-state entity in the earned sovereignty management process, the outcome is likely to be most successful.

The international community must establish a strategic framework to manage self-determination movements. Self-determination movements are a constant presence on the global scene. In the not too distant future, the international community face renewed calls for self-determination by the Kurdish populations in Iraq and Syria, and possibly Turkey, given the chaos that is raging through Iraq and Syria as a result of the rise of the Islamic State. ${ }^{148}$ Now is the time to think through a strategic framework that can regulate how states request, manage, and ultimately decide on selfdetermination. As illustrated above, there are instances of state practice and relevant discourse that may serve as a guide for the creation of a strategic policy ${ }^{149}$ The status quo of battling to independence is not sustainable and rewards the most violent actors. ${ }^{150}$ The clash between sovereignty and selfdetermination can no longer be left to fester and generate endless conflict.

148. See Simon Tisdall, Kurdistan faces long, fraught road to sustainable independence, THE GUARDIAN (July 3, 2014), available at http://www.theguardian.com/world/20/4/jul/03/kurdistansustainable-independence-iraq (last visited Feb. 7, 2015) (The Kurdish regional govemment (KRG) has steadily expanded its political and economic authority throughout the decade since Saddam Hussein's fall. The KRG has further intensified its efforts to expand its clout in the region since the collapse of central authority in Iraq. With the up rise of the Islamic State in Syria some argue that the Kurd's ability to combat the extremist group, while securing towns is a clear demonstration of the legitimacy of the Kurdish independence movement); Jenna Krajeski, Sebastian Meyer, A Litmus Test for Kurdistan: ISIS Tests Kurd's Bid for Independence, N.Y. TIMES (Sept. 30, 2014), available at http://www.nytimes.com/ 2014/10/01/opinion/isis-tests-kurds-bid-for-independence.html (last visited Feb. 7, 2015).

149. See generally Valerie Epps, The Paucity of Law in the ICJ's 2010 Advisory Opinion on Kosovo's Declaration of Independence, 19 ILSA J. INT'L \& COMP. L. 26, (2010); Ved P. Nanda, SelfDetermination in International Law-The Tragic Tale of Two Cities-Islamabad (West Pakistan) and Dacca (East Pakistan), 66 AM. J. INT'L L. 321 (1972); Ved P. Nanda, The New Dynamics of SelfDetermination: Revisiting Self-Determination as an International Law Concept: A Major Challenge in the Post-Cold War Era, 3 ILSA J. INT'L \& COMP. L. 443, 444 (1997); Paul R. Williams, Michael P. Scharf \& James R. Hooper, Resolving Sovereignty-Based Conflicts: The Emerging Approach of Eamed Sovereignty, 31 DENV. J. INT'L L. \& POL'Y 349, 353 (2003); Valerie Epps, Self-Determination in the Taiwan/China Context, 32 NEw ENG. L. REV. 685 (1998).

150. Paul Williams, Speech: International Law, Politics, and the Future of Kosovo, (Feb. 17, 2008). 